\title{
Determination of radon exhalation from granite, dolerite and marbles decorative stones of the Azad Kashmir area, Pakistan
}

\author{
M. Rafique $\cdot$ M. H. Rathore
}

Received: 18 June 2011/Revised: 15 April 2012/Accepted: 15 December 2012/Published online: 17 May 2013

(C) Islamic Azad University (IAU) 2013

\begin{abstract}
Extensive export quality reserves of granite, dolerite and marbles which are used for interior decorations as wall facing, paving floors, kitchen counter tops, etc., are available in Azad Kashmir. Since these stones contain radium in trace amounts, therefore, its use as a building material may be a potential source of indoor radon. In order to assess health hazards due to the use of these stones as a building material, samples were collected from different mining sites. After processing, these samples were placed in plastic containers and box type radon detectors were installed in it at the height of $25 \mathrm{~cm}$ above the surface of the samples. The containers were then hermetically sealed. After 60 days of exposure to radon, CR-39 detectors were etched in $6 \mathrm{M} \mathrm{NaOH}$ at $70{ }^{\circ} \mathrm{C}$ for $9 \mathrm{~h}$ and measured track densities were related to radon concentration. Radon exhalation rate form the studied granites, marble and dolerite samples varied from $87 \pm 26$ to $353 \pm 36 \mathrm{mBq} \mathrm{m}^{-2} \mathrm{~h}^{-1}, \quad 79 \pm 25$ to $\quad 650 \pm 42 \mathrm{mBq}$ $\mathrm{m}^{-2} \mathrm{~h}^{-1}$ and $90 \pm 26$ to $324 \pm 36 \mathrm{mBq} \mathrm{m}^{-2} \mathrm{~h}^{-1}$, respectively. These decorative stones are therefore used in buildings and for export purposes as the observed radon exhalation values are smaller than that of the EPA recommended-action level.
\end{abstract}

Keywords Radium - CR-39 detectors . Radon exhalation · Decorative stones

M. Rafique ( $\square)$

Department of Physics, University of Azad Jammu and Kashmir, Muzaffarbad, Azad Kashmir 13100, Pakistan

e-mail:mrafique@gmail.com

M. H. Rathore

AKMIDC, Muzaffarabad, Azad Kashmir, Pakistan

\section{Introduction}

Radon $\left({ }^{222} \mathrm{Rn}\right)$, a class A carcinogen, is a gaseous decay product of ${ }^{226} \mathrm{Ra}$, a naturally occurring radionuclide found in varying amounts in almost all rocks and soils. Being a noble gas, it has greater ability to migrate freely through soil underlying the houses and get trapped within closed rooms rising to elevated levels (Matiullah et al. 1993; Rahman et al. 2007a). A sustained radon exposure has been associated with an increase in the risk of lung cancer as reported by Smith (1988), Jacobi (1988) and Lubin (1999). Radon exposure is known to be the second leading cause of lung cancer after cigarette smoking (BEIR VI "Health Effects of Exposure to Radon” 1999). Radon mainly enters the buildings from the soil-underneath the foundations, emanation from ground water use, building materials, and from the outdoor air (Bertrand et al. 1994; Durrani and Ilic 1997). Building material usually consists of bricks, cement, gravels, sand, tiles, marbles and granite. Uses of decorative stones (granite, marble dolerite) to make rooms stylish and impressive have long been seen. Granite, dolerite and marble are decorative stones used in stair floors and kitchen tops, in columns, arches balusters, steps, windowsills, walls, tombstones mausoleums, statuaries and novelties like table top, book ends, lamp bases and others.

These stone are mined from the earth's crust. The most elements in the earth's crust contain ${ }^{238} \mathrm{U}$ in trace amount, therefore, any material can be a potential radon emitter, and therefore, any building materials extracted from the earth's crust can potentially be radioactive. But the degree of threat posed by these construction materials varies, depending upon concentration of ${ }^{238} \mathrm{U}$ and ${ }^{226} \mathrm{Ra}$ contents (Al-Jarallah et al. 2001). Certain granites are part of uranium-rich bedrocks and used as building materials (Bertrand et al. 1994; Durrani and Ilic 1997). Granite is a form of igneous rock, which is composed primarily of Quartz, Alkalie and Feldspar. The 
decorative stones (granite, dolerite and marble) contain slightly higher amount of ${ }^{238} \mathrm{U}$ and ${ }^{226} \mathrm{Ra}$ contents as compared to other building materials and are thought to be sources of airborne radioactivity and external radiation from the decay series of uranium in buildings.

In the past several decades, radon exhalation rate from building materials has remained the subject of many studies (Abu-Jarad et al. 1980; Tufail et al. 2000; Rahman et al. 2007b, 2009, 2008; Ahmed et al. 1998; Matiullah et al. 2004). Since building materials are a significant source of indoor radon, therefore, remedial actions have to be taken in addition to the ventilation to reduce the concentration of indoor radon.

This work deals with determination of radon exhalation from the locally mined export quality decorative stones and is a continuation of our previous studies (Rafique et al. 2008, 2009, 2010). The main objective of this work is to set up radon baseline data and to find out whether or not these decorative stones are safe to be exported for use in construction of buildings.

Geology of decorative stones in Azad Kashmir

Granite, dolerite and marble are decorative stones, which are mined in many places in the Azad Kashmir, Pakistan. The mining locations include Nauseri, Jura, Keran, Kel, Kundal Shahi and around Taobat areas in Neelum Valley as may be seen in Fig. 1 .
Granite

Salt and pepper type granite is found in Jura, kundal shahi and along the Neelum Valley road in the district Muzaffarabad. Owing to its hardness and appealing colours, this rock is extensively being used as a decorative stone in buildings. Preliminary geological investigations have identified extensive reserves of granite, dolerite and marbles (Fig. 2).

The Mansehra type leucogranite outcrops are present in the studied area. It forms sheet like pluri-kilomtric bodies isoclinally folded together with the other geological units. Generally, the core of the sheet is massive or less deformed than the peripheral zone where it rather appears as a leucocratic orthogneiss. Its chemical and mineral compositions range from granite to granodiorite. The typical mineral assemblage includes quartz, plagioclase, potash feldspar, muscovite, biotite and accessory, garnet, and tourmaline (Schouppe et al. 1993).

Granite characteristically contains more than $70 \%$ silica and relatively high soda and potash $\mathrm{No}_{2}+\mathrm{k}_{2} \mathrm{O}$ which ranges from 5 to $12 \%$, and $\mathrm{MgO}$ content is usually $<1 \%$. Granite occurs exclusively as intrusive bodies, and may occur in almost any forms like dyke, Sills, plugs, basses, ring complexes. The leucogranite of the Neelum valley can be correlated with the 516 My old Mansehra granite of the western side of the Hazara Kashmir Syntaxis and with the 400-500 My old Shengus Gneiss of the Nanga Parbat area (Fig. 3).

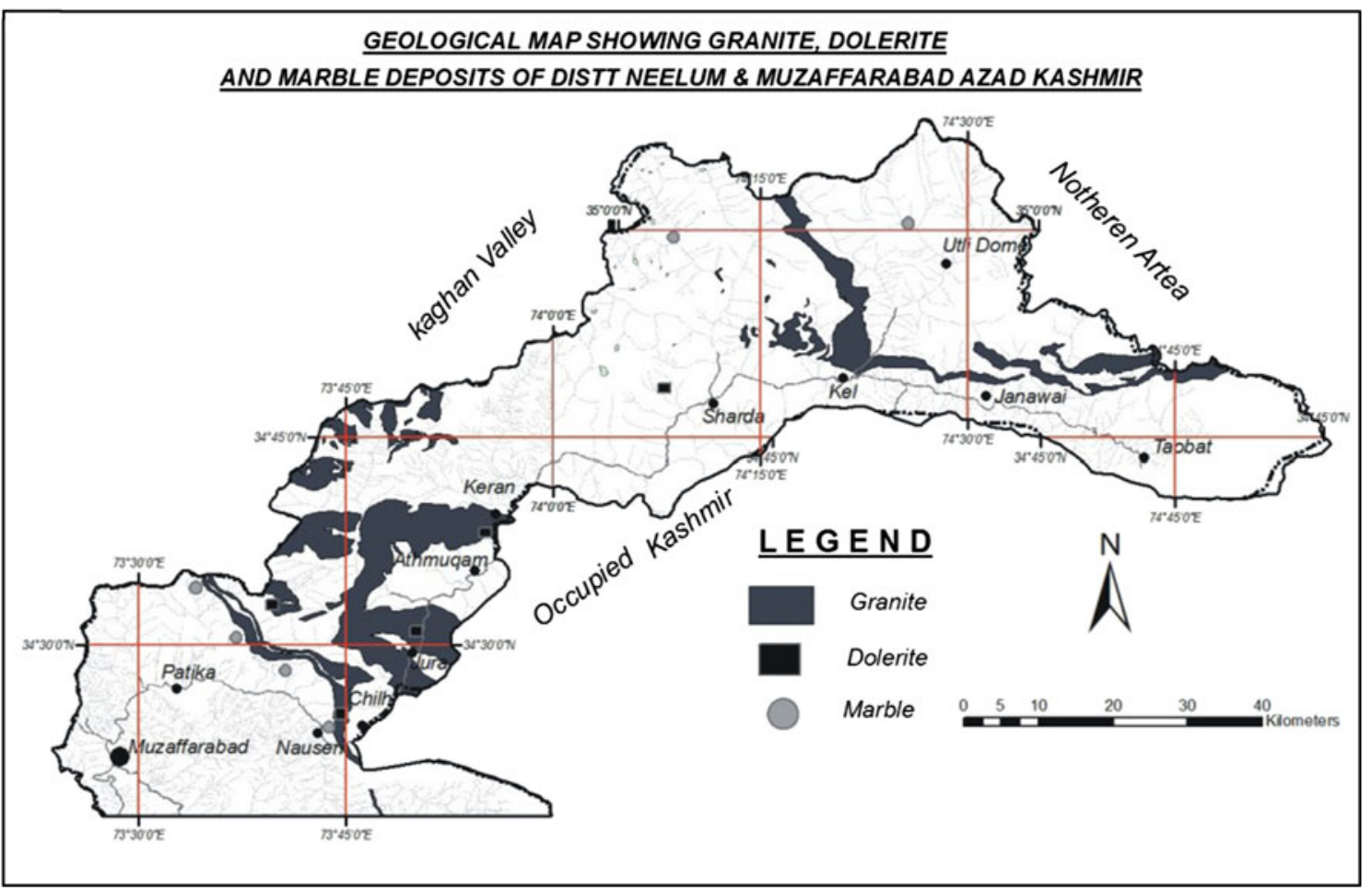

Fig. 1 Geological map showing granite, dolerite and marble reserves in districts Neelum and Muzaffarabad 

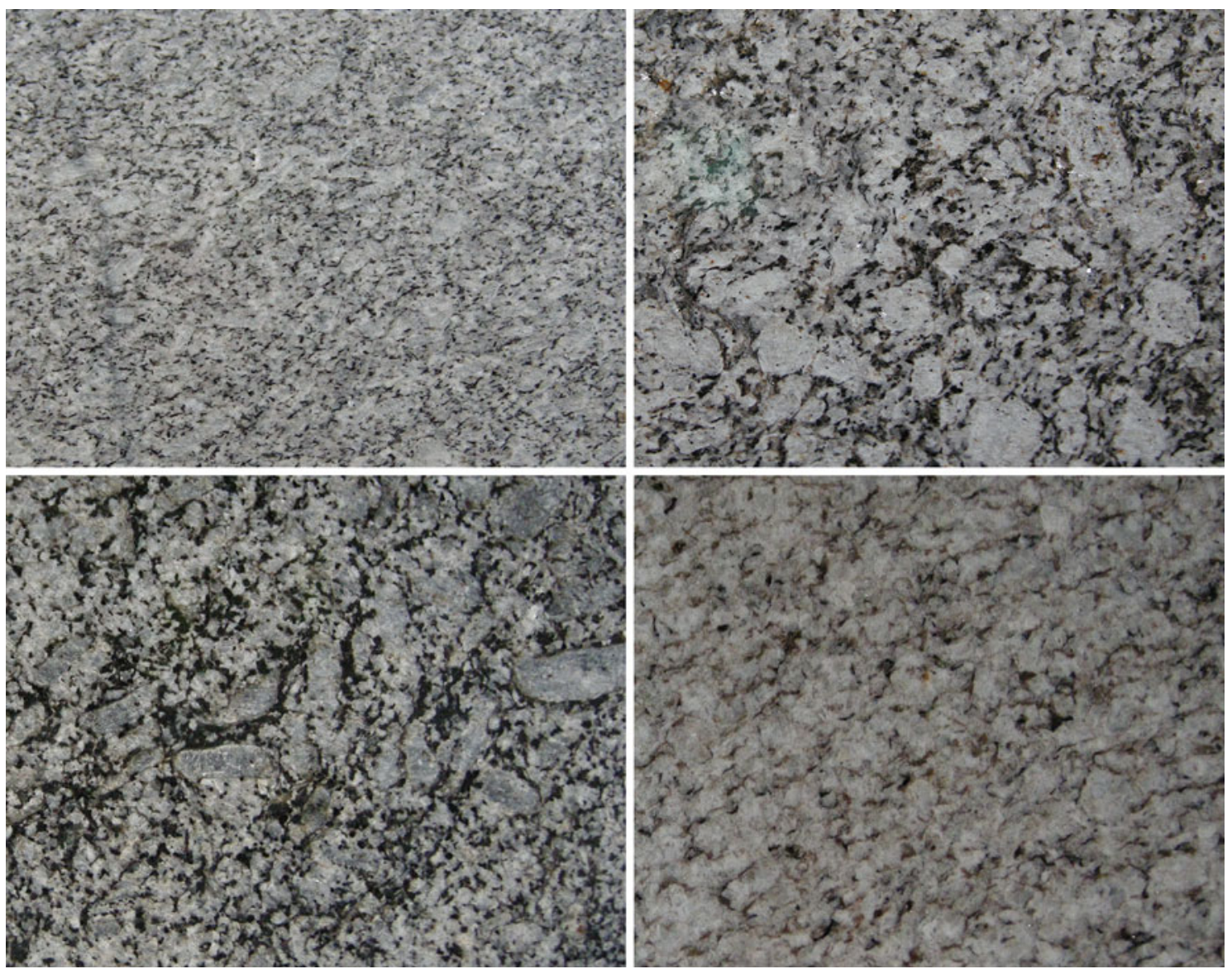

Fig. 2 Types of granite stones found in Azad Kashmir, Pakistan

\section{Dolerite}

It is medium-grained basic igneous rock, is mineralogical and chemically same as gabbro and basalt. Dolerite occurs mainly as dykes, sills and plugs, which are often old volcanic rocks. Mineralogically it is glassy basic igneous rock. The essential minerals are calcic plagioclase, pyroxene, with or without olivine; magnetite is an important accessory, whilst quartz hornblende and hypersthenes are some time present in significant amount. Basalts/dolerites contain low $\mathrm{SiO} 2$ content. (45-50\%), having high content of $\mathrm{FeO}, \mathrm{MgO}$ and $\mathrm{CaO}$ whilst $\mathrm{Na}_{2} \mathrm{O}$ and $\mathrm{k}_{2} \mathrm{O}$ are low.

\section{Marble}

Marble is used as a dimension stone for facing walls, paving floors and in the manufacturing of terrazzo tiles. Several marble occurrences have been discovered in the districts Muzaffarabad and Neelum. The thickness of these marble ranges from 3 to $25 \mathrm{~m}$ and the strike extension is $200 \mathrm{~m}$ to $17 \mathrm{~km}$. Significant deposits of snow white to appealing shades of yellowish green marbles have been discovered in the Nauseri, Treri, Jhugian areas in the

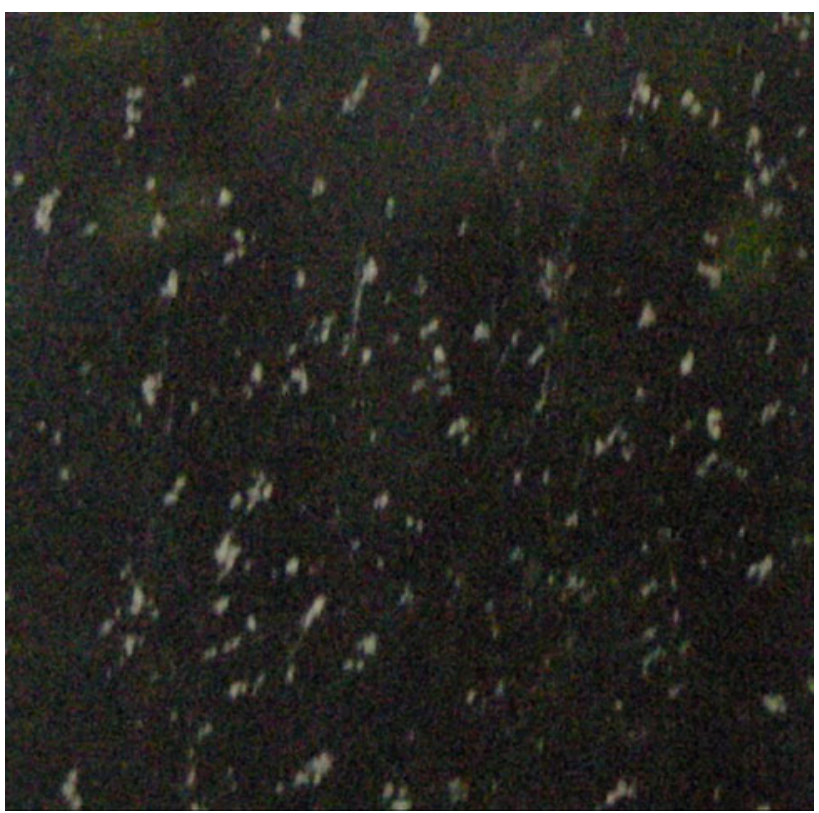

Fig. 3 Dolerite a decorative stone found in Azad Kashmir, Pakistan district Muzaffarabad and Dhanwan area in the Kotli district. Geological reserves of these deposits are more than 20 million tons. The Nauseri marble, which is $17 \mathrm{~km}$ in 
length, is pure white in colour with occasional grey bands and fine grained. It takes good polish and is being mined by private sector. Other marble beds located in the area have very low quality and thickness.

\section{Materials and methods}

In order to carry out the present work, 'can' technique was used to measure the radon exhalation from the most commonly used decorative stones, namely granite, dolerite and marbles. In this regard, 25 samples of granite, ten samples of marbles and 15 samples of dolerite were collected from different mining locations in the Azad Kashmir, Pakistan. All the samples were crushed and dried for $4 \mathrm{~h}$ in an oven at $110{ }^{\circ} \mathrm{C}$. These samples (each weighting $500 \mathrm{~g}$ ) were then put into plastic cans of volume $8.55 \times 10^{3} \mathrm{~cm}^{3}$. CR39 based box type detectors were installed in cans at height of $25 \mathrm{~cm}$ from the surface of the samples. The cans were then hermetically sealed and the detectors were exposed to radon for 60 days. After the exposure, CR-39 detectors were etched in $6 \mathrm{M} \mathrm{NaOH}$ at $70{ }^{\circ} \mathrm{C}$ for $9 \mathrm{~h}$ and tracks were counted under an optical microscope. After the background correction, track densities were related to the radon concentrations $\left(\mathrm{Bq} \mathrm{m}^{-3}\right)$ using a calibration factor of 0.0092 tracks $\mathrm{cm}^{-2} \mathrm{~h}^{-1}=1 \mathrm{~Bq} \mathrm{~m}^{-3}$ of ${ }^{222} \mathrm{Rn}$ (Khan et al. 1991). Experimental arrangements concerning measurement of radon exhalation are shown in the Fig. 4.

\section{Radon exhalation rate measurement}

Like other natural stones, granite, marble and dolerite decorative stones also contain trace amounts of naturally occurring radionuclide like ${ }^{238} \mathrm{U},{ }^{226} \mathrm{Ra}$, etc. Radium decays into ${ }^{222} \mathrm{Rn}$ by emitting $\alpha$-particle. ${ }^{222} \mathrm{Rn}$ that

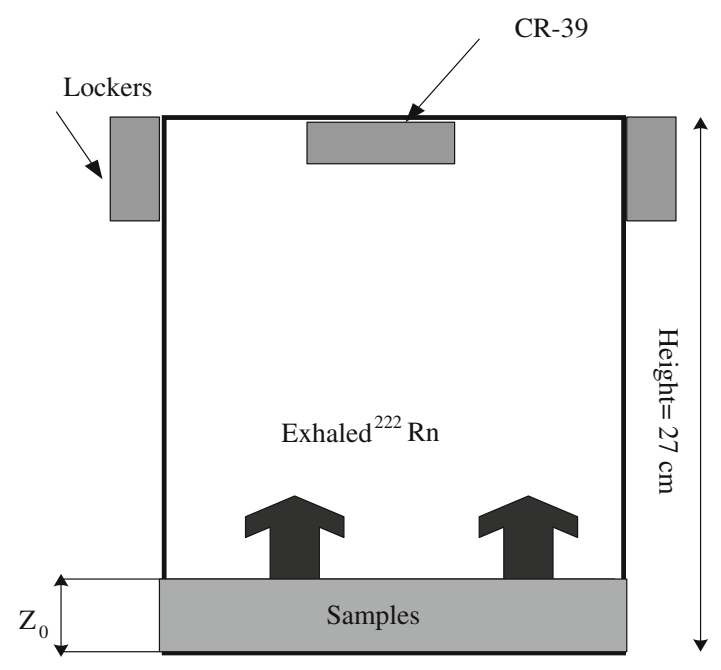

Fig. 4 Experimental set up for measuring radon exhalation rate escapes from the mineral grain enters into the pore spaces and is transported to the indoor environment (Semkow 1990). Most of the radon produced remains within the grain and only a small fraction of it escapes to the pore spaces. This escaped fraction of radon to the pore spaces is called emanation coefficient. Radon emanation depends on numbers of factors (1) ${ }^{226} \mathrm{Ra}$ distribution and its concentration in the grain, (2) grain size, (3) water contents in pore spaces, (4) porosity, etc. (Sasaki et al. 2004; Duenas et al. 1997). Only a fraction of the atoms produced by emanation reaches the surface of the soil and is called exhalation.

Diffusion and convection mechanisms are responsible for the transport of radon in any medium. In current study, we have measured radon exhalation for each sample of decorative stone using the methodology adopted by Rehman et al. (2006b). For this purpose, radon concentration was experimentally found using CR-39 plastic track detectors. The following relation was used to determine radon exhalation rate:

$F_{0}=\frac{C(t)[\omega A+\lambda V]}{A\left[1-e^{-\left(\frac{\omega A}{V}+\lambda\right) t}\right]}$,

and for taking into account the back diffusion factor, the corrected value of radon exhalation rate is given by the following expression:

$F=F_{0}-\omega C$,

where

$A$ is the surface area of the sample $\left(\mathrm{cm}^{2}\right), V$ is the volume of void space in closed chamber, $t$ is the radon accumulation time in the closed chamber. $\omega=\varepsilon \lambda Z_{0}$ is known as a back diffusion constant for given material, $Z_{0}$ is the thickness of sample in sealed chamber, $C(t)$ is the concentration of ${ }^{222} \mathrm{Rn}$ just on the surface of sample, which has to be exhaled from the surface of sample to void space of chamber,

$F_{0}=R \rho_{b} \lambda E Z_{0}$,

where

$\lambda$ is the ${ }^{222} \mathrm{Rn}$ decay constant $\left(\mathrm{h}^{-1}\right), \rho_{b}$ is bulk density of the sample $\left(\mathrm{kgm}^{-3}\right), E$ is the sum of fractional emanation coefficient of ${ }^{222} \mathrm{Rn}$ in air, water and adsorbed phase $\left(E_{\text {air }}+E_{\text {water }}+E_{\text {solid }}\right), R$ is the concentration of ${ }^{226} \mathrm{Ra}$ $\left(\mathrm{Bq} \mathrm{Kg}{ }^{-1}\right)$.

Putting the value of $C(t)$ in Eq. (1), exhalation rate, $F_{0}$, was determined. In a closed chamber that contains a sample, ${ }^{222} \mathrm{Rn}$ concentration increases with the passage of time from zero to its maximum value. After reaching its maximum value, back diffusion of radon also takes place, which reduces the ${ }^{222} \mathrm{Rn}$ concentration by a factor $\omega$ in the chamber. Therefore, exhalation rate $F$, corrected for back diffusion, was determined using Eq. (2). 
Table 1 Radon exhalation rate from Granite samples collected from the Neelum valley, Jhelum valley and Muzaffarabad city

\begin{tabular}{|c|c|c|c|c|}
\hline Sample type & Location & $\begin{array}{l}\text { Exposure time } \\
\text { (days) }\end{array}$ & $\begin{array}{l}\text { (Radon concentration } \pm \text { error) } \\
\left(\mathrm{Bq} \mathrm{m}^{-3}\right)\end{array}$ & 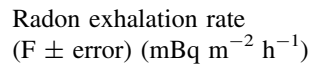 \\
\hline Granite 1 & Leswa & 60 & $174 \pm 8$ & $353 \pm 36$ \\
\hline Granite 2 & Leswa & 60 & $92 \pm 10$ & $186 \pm 31$ \\
\hline Granite 3 & Jhugian & 60 & $110 \pm 10$ & $223 \pm 32$ \\
\hline Granite 4 & Islampura & 60 & $115 \pm 9$ & $233 \pm 33$ \\
\hline Granite 5 & Islampura & 60 & $136 \pm 9$ & $276 \pm 34$ \\
\hline Granite 6 & Jhugian & 60 & $123 \pm 9$ & $249 \pm 33$ \\
\hline Granite 7 & Jhugian & 60 & $102 \pm 10$ & $207 \pm 32$ \\
\hline Granite 8 & Keran & 60 & $118 \pm 9$ & $239 \pm 33$ \\
\hline Granite 9 & Taobat & 60 & $108 \pm 10$ & $218 \pm 32$ \\
\hline Granite 10 & Leswa & 60 & $154 \pm 9$ & $311 \pm 35$ \\
\hline Granite 11 & Keran & 60 & $111 \pm 10$ & $224 \pm 32$ \\
\hline Granite 12 & Jura & 60 & $124 \pm 9$ & $252 \pm 33$ \\
\hline Granite 13 & Jhugian & 60 & $122 \pm 9$ & $247 \pm 33$ \\
\hline Granite 14 & Jhugian & 60 & $109 \pm 10$ & $221 \pm 32$ \\
\hline Granite 15 & Khundal Shahi & 60 & $141 \pm 8$ & $287 \pm 34$ \\
\hline Granite 16 & Jura & 60 & $85 \pm 11$ & $172 \pm 30$ \\
\hline Granite 17 & Segam & 60 & $80 \pm 11$ & $163 \pm 30$ \\
\hline Granite 18 & Khundal Shahi & 60 & $83 \pm 11$ & $167 \pm 30$ \\
\hline Granite 19 & Khundal Shahi & 60 & $55 \pm 13$ & $112 \pm 27$ \\
\hline Granite 20 & Khundal Shahi & 60 & $67 \pm 12$ & $135 \pm 29$ \\
\hline Granite 21 & Leswa & 60 & $78 \pm 11$ & $159 \pm 30$ \\
\hline Granite 22 & Jura & 60 & $43 \pm 15$ & $87 \pm 26$ \\
\hline Granite 23 & Jura & 60 & $44 \pm 15$ & $89 \pm 26$ \\
\hline Granite 24 & Jura & 60 & $58 \pm 13$ & $119 \pm 28$ \\
\hline Granite 25 & Jura & 60 & $81 \pm 11$ & $165 \pm 30$ \\
\hline A.M & \multicolumn{2}{|c|}{ G.M } & S.D & G.S.D \\
\hline \multicolumn{5}{|c|}{ A.M, G.M, S.D and G.S.D values of radon concentration from granite samples $\left(\mathrm{Bq} \mathrm{m}^{-3}\right)$} \\
\hline 101 & & & 34 & 1.36 \\
\hline \multicolumn{5}{|c|}{ A.M, G.M, S.D and G.S.D values of radon exhalation rate from granite samples $\left(\mathrm{mBq} \mathrm{m} \mathrm{m}^{-2} \mathrm{~h}^{-1}\right)$} \\
\hline 204 & & & 68 & 1.36 \\
\hline
\end{tabular}

\section{Results and discussion}

Radon exhalation from decorative stones may contribute towards the significant radiation doses. In this regards, studies have been carried out in different parts of the world and extensive data are available in the literature. As mentioned earlier, vast deposits of the above-mentioned export quality decorative stones have been found in Azad Kashmir. In order to determine radon exhalation from these stones and hence dose delivered to dwellers, granite, marble and dolerite samples were collected from the district Muzaffarabad and Neelum. Places of collection of granite samples included Leswa, Jhugian, Islampura, Keran, Taobat, Jura, Khundal Shahi and Segam (see Fig. 1).

Table 1 shows measured values of radon exhalation rates from granite samples. The radon exhalation rate is seen to vary from $87 \pm 26$ to $353 \pm 36 \mathrm{mBq} \mathrm{m}^{-2} \mathrm{~h}^{-1}$. A minimum value for radon exhalation rate is found for granite sample collected from Jura, whilst maximum radon exhalation rates are found in sample collected from Leswa. Arithmetic mean, geometric mean, standard deviation and geometric standard deviation of radon concentrations for the studied granites samples are 101, 95, 34 and 1.36, respectively. No significant difference has been observed in radon exhalation rate from the studied samples.

Table 2 shows radon exhalation rate from marble samples, which were collected from Tereri, Nasuri and Jhugian locations in district Neelum, Azad Kashmir. Radon exhalation rate from marble samples varies from $79 \pm 25$ to $651 \pm 42 \mathrm{mBq} \mathrm{m}^{-2} \mathrm{~h}^{-1}$. A minimum value for radon exhalation was observed from a sample, which was collected from Nuseri, whilst maximum radon exhalation rate are found for the sample collected from Treri. The arithmetic mean, geometric mean, standard deviation and geometric standard deviation of radon concentrations reported for marble samples are $88,70,85$ and 1.37 , respectively.

Table 3 shows radon exhalation from dolerite samples, which were collected from different locations in district 
Table 2 Radon exhalation rate from Marble and Dolerite samples collected from the Azad Kashmir, Pakistan

\begin{tabular}{|c|c|c|c|c|}
\hline Sample type & Location & $\begin{array}{l}\text { Exposure } \\
\text { time (days) }\end{array}$ & $\begin{array}{l}\text { (Radon concentration } \pm \text { error) } \\
\left(\mathrm{Bq} \mathrm{m}^{-3}\right)\end{array}$ & $\begin{array}{l}\text { Radon exhalation rate } \\
(\mathrm{F} \pm \text { error })\left(\mathrm{mBq} \mathrm{m} \mathrm{m}^{-2} \mathrm{~h}^{-1}\right)\end{array}$ \\
\hline Marble 1 & Nuseri & 60 & $45 \pm 15$ & $92 \pm 30$ \\
\hline Marble 2 & Treri & 60 & $60 \pm 13$ & $122 \pm 26$ \\
\hline Marble 3 & Jhugian & 60 & $66 \pm 12$ & $134 \pm 24$ \\
\hline Marble 4 & Jhugian & 60 & $51 \pm 14$ & $103 \pm 28$ \\
\hline Marble 5 & Treri & 60 & $55 \pm 14$ & $111 \pm 28$ \\
\hline Marble 6 & Jhugian & 60 & $66 \pm 12$ & $134 \pm 24$ \\
\hline Marble 7 & Jhugian & 60 & $57 \pm 13$ & $116 \pm 26$ \\
\hline Marble 8 & Nuseri & 60 & $39 \pm 16$ & $79 \pm 32$ \\
\hline Marble 9 & Treri & 60 & $321 \pm 6$ & $651 \pm 12$ \\
\hline Marble 10 & Jhugian & 60 & $122 \pm 9$ & $247 \pm 18$ \\
\hline A.M & & & S.D & G.S.D \\
\hline \multicolumn{5}{|c|}{ A.M, G.M, S.D and G.S.D values of radon concentration from marble samples $\left(\mathrm{Bq} \mathrm{m}^{-3}\right)$} \\
\hline 88 & & & 85 & 1.37 \\
\hline \multicolumn{5}{|c|}{ A.M, G.M, S.D and G.S.D values of radon exhalation rate from marble samples ( $\mathrm{mBq} \mathrm{m}^{-2} \mathrm{~h}^{-1}$ ) } \\
\hline 195 & & & 175 & 1.4 \\
\hline
\end{tabular}

Table 3 Radon exhalation rate from Dolerite samples collected from the Azad Kashmir, Pakistan

\begin{tabular}{|c|c|c|c|c|}
\hline Sample type & Location & $\begin{array}{l}\text { Exposure } \\
\text { time (days) }\end{array}$ & $\begin{array}{l}\text { (Radon concentration } \pm \text { error) } \\
\left(\mathrm{Bq} \mathrm{m}^{-3}\right)\end{array}$ & $\begin{array}{l}\text { Radon exhalation rate } \\
(\mathrm{F} \pm \text { error })\left(\mathrm{mBq} \mathrm{m}^{-2} \mathrm{~h}^{-1}\right)\end{array}$ \\
\hline Dolerite 1 & Keran & 60 & $148 \pm 8$ & $300 \pm 16$ \\
\hline Dolerite 2 & Jura & 60 & $80 \pm 11$ & $162 \pm 23$ \\
\hline Dolerite 3 & Jura & 60 & $44 \pm 15$ & $89 \pm 30$ \\
\hline Dolerite 4 & Jhugian & 60 & $84 \pm 11$ & $170 \pm 23$ \\
\hline Dolerite 5 & Khundal Shahi & 60 & $75 \pm 12$ & $152 \pm 24$ \\
\hline Dolerite 6 & Neelum Valley & 60 & $86 \pm 11$ & $174 \pm 23$ \\
\hline Dolerite 7 & Khundal Shahi & 60 & $72 \pm 12$ & $146 \pm 24$ \\
\hline Dolerite 8 & Neelum Valley & 60 & $57 \pm 13$ & $116 \pm 27$ \\
\hline Dolerite 9 & Jhugian & 60 & $60 \pm 13$ & $122 \pm 27$ \\
\hline Dolerite 10 & Jura & 60 & $55 \pm 14$ & $111 \pm 28$ \\
\hline Dolerite 11 & Khundal Shahi & 60 & $59 \pm 13$ & $120 \pm 26$ \\
\hline Dolerite 12 & Neelum Valley & 60 & $160 \pm 8$ & $324 \pm 16$ \\
\hline Dolerite 13 & Segam & 60 & $98 \pm 10$ & $199 \pm 21$ \\
\hline Dolerite 14 & Leswa & 60 & $62 \pm 13$ & $126 \pm 26$ \\
\hline Dolerite 15 & Khundal Shahi & 60 & $61 \pm 13$ & $124 \pm 26$ \\
\hline A.M & \multicolumn{2}{|c|}{ G.M } & S.D & G.S.D \\
\hline \multicolumn{5}{|c|}{ A.M, G.M, S.D and G.S.D values of radon concentration from dolerite samples $\left(\mathrm{Bq} \mathrm{\textrm {m } ^ { - 3 } )}\right.$} \\
\hline 80 & & & 33 & 1.25 \\
\hline \multicolumn{5}{|c|}{ A.M, G.M, S.D and G.S.D values of radon exhalation rate from dolerite samples $\left(\mathrm{mBq} \mathrm{m}{ }^{-2} \mathrm{~h}^{-1}\right)$} \\
\hline \multicolumn{2}{|l|}{162} & & 67 & 1.25 \\
\hline
\end{tabular}

Neelum (see Fig. 1). Radon exhalation rate from dolerite samples ranges from $89 \pm 30$ to $324 \pm 16 \mathrm{mBq}$ $\mathrm{m}^{-2} \mathrm{~h}^{-1}$. Minimum values of radon exhalation rate have been observed from a sample, collected from Jura, whilst maximum radon exhalation rate has been reported for sample \#12 collected from Neelum valley. Arithmetic mean, geometric mean, standard deviation and geometric standard deviation of radon concentrations reported for dolerite sample are 80, 75, 33 and 1.25, respectively.

Comparison of A.M and G.M values of radon exhalation rate from decorative stones is shown in Fig. 5. In this figure, granite is seen to contribute more than those of marble and dolerite samples. On the other hand, marble samples 
Fig. 5 Comparison of A.M and G.M values of radon exhalation rates for the studied decorative stones

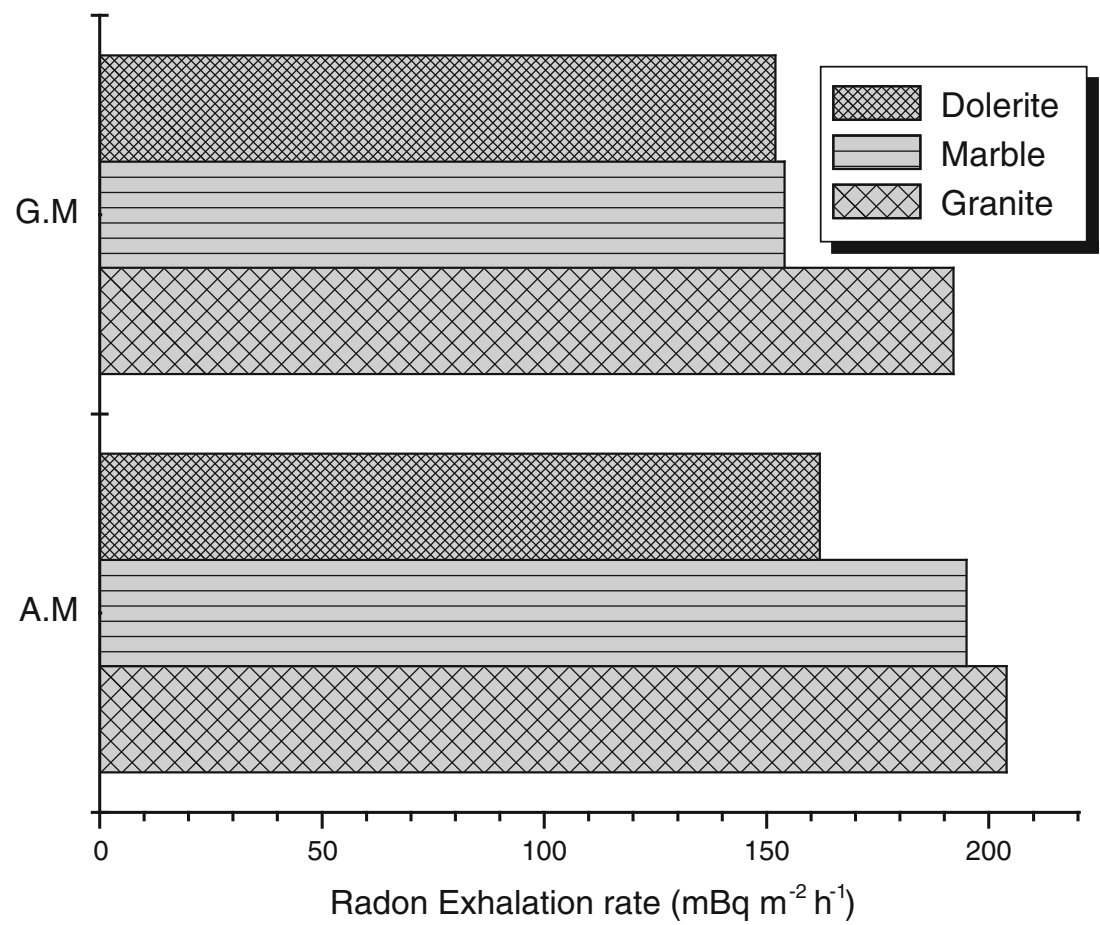

Table 4 Comparison of current data of radon exhalation rate with the values reported for other countries of the world

\begin{tabular}{llll}
\hline Reference & Location & Sample type & $\begin{array}{l}\text { (Average radon exhalation } \\
\text { rate } \pm \mathrm{SD})\left(\mathrm{mBq}^{-2} \mathrm{~h}^{-1}\right)\end{array}$ \\
\hline Amrani and Cherouati ( 1999) & Algeria & Granite & $47-89$ \\
& & Marble & $35-66$ \\
Maged and Ashraf ( 2005) & Egypt & Marble & 608 \\
& & Granite & 1412 \\
Al-Jarallah et al. (2001) & Saudi Arabia & Granite & 720 \\
Faheem et al. (2008) & Pakistan & Marble & $120 \pm 13$ \\
Oufni (2003) & Morocco & Quaternary samples & $3-145$ \\
Shweikani and Hushari (2005) & Syria & Soil & $72,000-32,400,000$ \\
Rahman et al. (2007) & NWFP, Pakistan & Sand, soil bricks & $(261,265,292)$ \\
UNSCEAR (2000) & World average radon exhalation rate & & 57,600 \\
Current study & Azad Kashmir, Pakistan & Granite marble dolerite & $87 \pm 26$ to $353 \pm 36,79 \pm 25$ \\
& & & to 650 $\pm 42,90 \pm 26$ to $324 \pm 36$ \\
\hline
\end{tabular}

$S D$ standard deviation

${ }^{a}$ unit used is $\left(\mathrm{m} \mathrm{Bq}^{-1} \mathrm{~kg}^{-1} \mathrm{~h}^{-1}\right)$

have broader range of radon exhalation values. Dolerite stones have the lowest radon exhalation rate.

Referring to Table 4, significant variation is seen in the radon exhalation rate from building materials reported from different countries of the world. A lowest value of radon exhalation rate (i.e. $3.145 \mathrm{mBq} \mathrm{m}^{-2} \mathrm{~h}^{-1}$ ) has been reported for quaternary samples [Morocco] (Oufni 2003). For soil samples, very high values ranging 72,000-32,400,000 mBq $\mathrm{m}^{-2} \mathrm{~h}^{-1}$ are reported for Syria by Shweikani and Hushari (2005), and Amrani and Cherouati (1999) have reported radon exhalation rate varying from 47 to $89 \mathrm{mBq} \mathrm{m}^{-2} \mathrm{~h}^{-1}$ and 35 to $66 \mathrm{mBq} \mathrm{m}^{-2} \mathrm{~h}^{-1}$ for granite and marbles
(Algeria), respectively. For Saudi Arabia, Al-Jarallah et al. (2001) has reported average radon exhalation rate of $720 \mathrm{mBq} \mathrm{m}^{-2} \mathrm{~h}^{-1}$ for granite. Radon exhalation rates for granite, marbles and dolerite observed in the current study range from $87 \pm 26$ to $353 \pm 36,79 \pm 32$ to $651 \pm 12$, and $89 \pm 30$ to $324 \pm 16$ which are less than those reported by UNSCEAR (2000). Radon exhalation rates observed in the present study are well below the world average of $57,600 \mathrm{mBq} \mathrm{m}^{-2} \mathrm{~h}^{-1}$ and hence do not pose any health hazards to the residents of studied area. Moreover, as for radon exhalation is concerned, these stones are safe for exportation. 


\section{Conclusion}

Radon exhalation rate from granite, dolerite and marbles decorative stones of local origin has been determined with an aim to assess the contribution of individual material to the total indoor radon exposure of the inhabitants of Azad Kashmir and to check whether or not these stones are safe to be exported. Results obtained from the current study show that radon exhalation rates from granite have relatively higher values as compared to those of marble and dolerite stone. In general, radon exhalation rate from the investigated decorative stones is well below the EPA recommended-action level. Therefore, the studied decorative stones are safe to be used for home interior decoration purposes as well as for exportation.

Acknowledgments We are thankful to Pakistan Science Foundation, Higher Education Commission of Pakistan and the University of Azad Jammu \& Kashmir for providing funds for current project.

\section{References}

Abu-Jarad F, Fremlin JH, Bull R (1980) A study of radon emitted from building materials using plastic track detectors. Phys Med Biol 25(4):683-694 (12 pages)

Ahmed N, Matiullah, Hussein AJA (1998) Determination of natural radioactivity in Jordanian soil and building materials and the associated radiation hazards. J Environ Radioact 39:9-22 (14 pages)

Al-Jarallah MI, Abu-Jarad F, Fazal-ur-Rehman (2001) Determination of radon exhalation rates from tiles using active and passive techniques. Radiat Meas 34:491-495 (5 pages)

Amrani D, Cherouati DE (1999) Radon exhalation rate in building materials using plastic track detectors. J Radioanal Nucl Chem 242(2):269-271 (3 pages)

BEIR VI "Health Effects of Exposure to Radon" (1999) BEIR VI Committee on Health Risks of Exposure to Radon (BEIR VI) National Research Council (ISBN: 0-309-52374-5)

Bertrand BA, David V, Becker K, Stanley JG, Bennett GP, Ken K, Henry R, Edward B, Silberstein, Edward W (1994) Radon update: facts concerning environmental radon levels, mitigation strategies, dosimetry effects and guides. J Nucl Med 35(2):368-385

Duenas C, Fernandez MC, Carretero J, Liger E, Perez M (1997) Release of ${ }^{222} \mathrm{Rn}$ from some soils. Ann. Geophysicae 15:124-133

Durrani SA, Ilic R (1997) Radon measurements by etched track detectors: applications in radiation protection, earth sciences and the environment. World Scientific, Singapore

Faheem M, Mujahid SA, Matiullah (2008) Assessment of radiological hazards due to the natural radioactivity in soil and building material samples collected from six districts of the Punjab province-Pakistan. Radiat Meas 43:1443-1447

Jacobi W (1988) Lung Cancer risk from environmental exposure to radon daughters. Radiat Prot Dosimetry 24:19

Khan EU, Tufail M, Tahseen R, Din NA, Matiullah, Ansari F, Hao HX, Wang YL, Guo SL, Waheed A (1991) Environmental radioactivity in D.I. Khan and its adjacent areas-Pakistan. Nucl Tracks Radiat Meas 19:761-764

Lubin J (1999) Discussion: indoor radon and risk of lung cancer. Radiat Res 151:105-106
Maged AF, Ashraf FA (2005) Radon exhalation rate of some building materials used in Egypt Environmental. Geochem Health 27:485-489

Matiullah, Bashir A, Kudo K, Yang X (1993) Radon measurements in some houses of Tsukuba science city-Japan”. Nucl Tracks Radiat Meas 22:395-398 (4 pages)

Matiullah, Ahad A, Rehman S, Faheem M (2004) Measurement of radioactivity in the soil of Bahawalpur division, Pakistan. Radiat Prot Dosim 112:443-447

Oufni L (2003) Determination of the radon diffusion coefficient and radon exhalation rate in Moroccan quaternary samples using the SSNTD technique. J Radio Anal Nucl Chem 256(3):581-586

Rafique M, Shahida J, Ikram MS (2008) General public's and physicians' perception of health risk associated with radon exposure in the state of Azad Jammu and Kashmir. Public Health Nurs 25(4):327-335

Rafique M, Rahman SU, Jabeen S, Shahzad MI, Rahman S, Bukhari S, Nasir T, Matiullah (2009) Measurement and comparison of indoor radon levels in newand old buildings in the city of Muzaffarabad (Azad Kashmir), Pakistan: a pilot study. Radioisotopes 58:749-760

Rafique M, Rahman S, Rahman SU, Jabeen S, Shahzad MI, Rathore MH, Matiullah (2010) Indoor radon concentration measurement in the dwellings of district Poonch (Azad Kashmir) Pakistan. Radiat Prot Dosim 138:158-165

Rahman S, Matiullah, Rahman Z, Mati N, Ghauri BM (2007a) Measurement of indoor radon levels in North West Frontier Province and federally administered tribal areas-Pakistan during summer. Radiat Meas 42(2):304-310

Rahman S, Mati N, Matiullah, Ghauri BM (2007b) Radon exhalation rate from the soil, sand and brick samples collected from NWFP and FATA, Pakistan. Radiat Prot Dosim 124(4):392-399 (8 pages)

Rahman S, Matiullah, Mujahid SA, Hussain S (2008) Assessment of the radiological hazards due to naturally occurring radionuclides in soil samples collected from the North Western areas of Pakistan. Radiat Prot Dosim 128:191-197 (7 pages)

Rahman SU, Rafique M, Matiullah, Anwar J (2009) Indoor radon concentrations and assessment of doses in four districts of the Punjab province-Pakistan. J Radiat Res 50:529-535 (7 pages)

Rehman S, Imtiaz N, Faheem M, Matiullah (2006) Determination of $238 \mathrm{U}$ contents in ore samples using CR-39 based radon dosimeter-disequilibrium case. Radiat Meas 41:471-476 (6 pages)

Sasaki T, Gunji Y, Okuda T (2004) Demonstration of a method to suppress radon emanation from uranium bearing wastes. Nucl Sci Technol 41(8):843-849

Schouppe M, Fontan D, Verkaeren J, Laduron D, Martinotti (1993) Regional geological mapping and ore potential assessment in Nelum valley, Azad Kashmir, Pakistan. Periodical report, EEC CI1-0571-M (GDF), 27

Semkow TM (1990) Recoil-emanation theory applied to radon release from mineral grains. Geochim Cosmochim Acta 54:425-440

Shweikani R, Hushari M (2005) The correlations between radon in soil gas and its exhalation and concentration in air in the southern part of Syria. Radiat Meas 40:699-703

Smith H, ICRP Publication 50 (1988) Lung cancer risk from indoor exposures to radon daughters. J Can Assoc Radiol 39(Supplement 1):144-147

Tufail M, Mirza SM, Mahmood A, Qureshi AA, Arfat Y, Khan HA (2000) Application of a closed-can technique for measuring radon exhalation from mine samples of Punjab, Pakistan. J Environ Radioact 50:267-275

UNSCEAR (2000) Report of the United Nations Scientific Committee on the Effects of Atomic Radiation to the General Assembly. ANNEX B exposures from natural radiation sources 